\title{
The Relationship Between Coronary Collateral Circulation and In-hospital Mortality in Patients with First Acute Anterior STEMI
}

\author{
Ilk Akut Önduvar ST Elevasyonlu Miyokart Enfarktüsü Geçiren Hastalarda Koroner Kollateral \\ Dolașım ile Hastane İ̧i Ölüm Arasındaki Ilișki
}

\author{
Bernas Altıntaș', Barıș Yaylak² \\ ${ }^{1}$ Diyarbakur Gazi Yaşargil Education and Research Hospital, Department of Cardiology, Diyarbakrr; ${ }^{2}$ Siyami Ersek Thoracic and \\ Cardiovascular Surgery Training and Research Hospital, Department of Cardiology, İstanbul, Turkey
}

\begin{abstract}
Aim: The aim of the present study is to investigate the prognostic value of Coronary Collateral Circulation (CCC) in patients with the first acute anterior wall ST Elevation Myocardial Infarction (STEMI) undergoing primary percutaneous coronary intervention $w(p-P C l)$.

Material and Method: A total of 220 Patients with first acute Anterior STEMI within first 6th hours undergoing $\mathrm{p}-\mathrm{PCl}$ were divided into 2 groups with respect to absence of CCC and presence of CCC. Coronary collateral flow to the infarct related artery (IRA) was graded on baseline angiograms with the use of qualitative classification by Rentrop.

Results: $A$ total of 220 patients mean age was of $61.4 \pm 12.3$ years with first acute Anterior STEMI undergoing $p$-PCl were included the study. 34\% of patients had CCC. The present study consisted of 64 female (29\%) and 156 male (71\%) patients. There were no statistically significant differences in respect to demographic characteristics, risk factors of coronary artery disease, LVEF, KILLIP classes, time from symptomps onset to $\mathrm{PCl}$, door to baloon time, preprocedural and postprocedural angiographic characteristics and clinical outcomes which included cardiogenic shock on admission, cardiogenic shock in-hospital, fatal ventricular arrhtymias, complet AV block, mechanical complications and in-hospital mortality between the groups. In a stepwise backward multivariable logistic regression model, the independent prognostic indicators for in-hospital mortality were age (odds ratio [OR] 1.08, 95\% Cl 1.07 to 1.26, $p=0.03$ ), Time from symptoms onset to $\mathrm{PCl}$ (odds ratio [OR] 1.6, $95 \% \mathrm{Cl} 1.06$ to $2.59, p=0.04$ ) and unsuccessful $p-P C l$ (odds ratio [OR] 3.3, 95\% Cl 1.04 to $10.9, p=0.04$ ).
\end{abstract}

Conclusion: Presence of CCC was not associated with in-hospital mortality in patients presenting with first acute Anterior STEMI undergoing $\mathrm{p}-\mathrm{PCl}$ within first 6 th hours.

Key words: acute anterior STEMI; coronary collateral circulation; in-hospital mortality

Bernas Altıntaş, Peyas Mahallesi Selahaddin Eyyubi Bulvarn 229. Sokak Hamzaoğulları Sitesi B/20 Kayapınar/Diyarbakır 21070 Diyarbakır - Türkiye, Tel.05330255045Email.drbernasemre@yahoo.com

Geliş Taribi: 25.07.2017 • Kabul Tarihi: 21.12.2017

\section{ÖZET}

Amaç: Çalıșmada ilk akut önduvar ST Elevasyonlu Miyokart Enfarktüsü (STEMI) geçirip Primer Perkütan Koroner Girișim (p-PKG) uygulanmıș hastalarda Koroner Kollateral Dolașımın (KKD) prognostik değerinin araștırımasını amaçlanmaktadır.

Materyal ve Metot: ilk akut önduvar STEMI geçiren, ilk 6 saat içinde p-PKG uygulanan toplam 220 hasta KKD varlığı ve yokluğuna göre 2 gruba ayrıldı. Bașlangıç anjiogramlarda, enfarkttan sorumlu artere doğru olușan koroner kollateral kan akımı Rentrop kalitatif sınıflama yöntemi kullanılarak derecelendirildi.

Bulgular: Illk akut önduvar STEMI geçiren p-PKG uygulanan or-

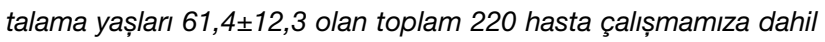
edildi. Hastaların \%34'ünde KKD mevcuttu. Çalıșmamıza alınan hastaların 64'ü (\%29) kadın 156'sı (\%71) erkekler olușturmaktaydı. Gruplar arasında demografik özellikler, sol ventrikül ejeksiyon fraksiyonu, KILLIP sınıfları, koroner arter hastalığı risk faktörleri, semptomların bașlangıcından p-PCl yapılıncaya kadar geçen süre, balon-kapı süresi, periprosedürel ve postprosedürel anjiografik özellikler ile bașvuru anında Kardiyojenik Șok, Hastane içi Kardiyojenik Șok, Ölümcül Ventriküler Aritmiler, Komplet AV blok, Mekanik Komplikasyonlar ve Hastane içi Ölümü içeren klinik sonlanımlar arasında istatiksel olarak anlamlı farkılık mevcut değildi. Çoklu değișkenli logistik regresyon analizinde yaș ([OR] 1,08, $95 \% \mathrm{Cl} 1,07$ to 1,26, $p=0,03$ ), Semptomların bașlangıcından p-PKG yapılıncaya kadar geçen süre ([OR] 1,6, $95 \% \mathrm{Cl} 1,06$ to 2,59, $p=0,04$ ), bașarısız p-PKG ([OR] 3,3, $95 \% \mathrm{Cl}$ 1,04 to 10,9, $p=0,04)$ hastane-içi ölüm için bağımsız tahmin ettiriciler olarak olarak bulundu.

Sonuç: Çalıșmada ilk akut önduvar STEMI geçiren, ilk 6 saat içinde p-PKG uygulanan hastalarda KKD ile hastane-içi ölüm arasında ilișki tespit edilememiștir.

Anahtar kelimeler: akut önduvar STEMI; koroner kollateral dolașım; hastane içi ölüm 


\section{Introduction}

Coronary Collateral Circulation (CCC) is an alternative source of blood supply for myocardium. Theoretically CCC is assumed to play an important role for keeping viability of jeopardized myocardium in critical stenosis of related epicardial coronary arteries. Protective effect of CCC on myocardium have been shown in several animal and human angiographyic experimental studies ${ }^{1-3}$. Also presence of well developed CCC and its impact on jeopardized myocardium and clinical outcomes were investigated especially in studies on chronic stable coronary artery disease with total occlusion (CTO) of coronary artery ${ }^{4-7}$.

Despite advances in medical and interventional therapies, acute myocardial infarction (AMI) is still a significant cause of mortality and morbidity. Percutaneous coronary intervention (PCI) has proven to be the best therapeutic option in patients with acute ST-segment elevation myocardial infarction (STEMI). Anterior STEMI are still associated with an increased mortality compared to other forms and locations of myocardial infarction ${ }^{8}$. Thus, various clinical and angiographic parameters have been searched to predict clinical outcomes among patients with anterior STEMI in the era of PCI. CCC can be one of those parameters.

Aim of this study was evaluate the preintevention angiographic evidence of CCC and in-hospital outcomes in patients with anterior STEMI who were undergone PCI.

\section{Material and Method}

Patients with first acute anterior STEMI undergoing primary PCI ( $\mathrm{p}$-PCI) were enrolled in this prospective study between February 2012 and June 2015. Inclusion criteria were as follows: onset of symptoms $<6$ hours before p-PCI; ST-segment elevation $>0.2$ $\mathrm{mV}$ in 2 contiguous precordial $\mathrm{V} 1, \mathrm{~V} 2$ leads and $>0.1$ $\mathrm{mV}$ in precordial V3-V6 leads with the left anterior descending artery (LAD) occlusion (Thrombolysis in Myocardial Infarction (TIMI) flow grade 0-1) as the infarct-related artery at baseline coronary angiography.

Left and right coronary angiograms were obtained before the attempted angioplasty with sufficient quality to assess the presence of collateral circulation via the filling of LAD and side branches by. Exclusion criteria were prior anterior $\mathrm{MI}$, venous graft-related infarcts, non-gradable collateral flow due to technical reasons, concurrent pericardial disease, chronic pulmonary disease, pulmonary hypertension, valvular heart disease (moderate to severe insufficiency and/or stenosis), acute pulmonary embolism, history of cardiac arrest before admission, renal failure (serum creatinin level $>1.5 \mathrm{mg} / \mathrm{dl}$ on admission). Informed consent of each subject and approval of the Local Ethics Committee were obtained.

\section{Coronary Angiography}

Coronary angiography (CAG) was performed within 90 minutes of hospital admission. All patients received dual antiplatelet therapy with aspirin $(300 \mathrm{mg})$ and clopidogrel $(600 \mathrm{mg})$ or ticagrelor $(180 \mathrm{mg})$ loading dose before CAG. Preprocedural anticoagulation consisted of intravenous unfractionated heparin (70 $\mathrm{IU} / \mathrm{kg}$ ) in all cases. Primary PCI with stent implantation was performed according to current guidelines? The purpose of the $\mathrm{p}$-PCI procedure was to obtain a residual stenosis of $<20 \%$ in the infarct-related artery (IRA) by visual evaluation. An optimal angiographic result was defined as presence TIMI grade 3 flow in the LAD following p-PCI. An unsuccessful procedure was defined as a procedure resulting in TIMI grade $0-1$ or 2 flow $^{10}$. Use of glycoprotein IIb/IIIa inhibitors (i. e. tirofiban) was left to the discretion of the attending physician. Complete ST-segment resolution was defined as a reduction of $>70 \%$ in the summed 12-lead extent of ST-segment elevation from baseline to the post-procedural electrocardiogram, which was recorded at $90^{\text {th }}$ minute after the first balloon inflation.

\section{Coronary Collateral Circulation}

Coronary collateral flow to the infarct-related artery was graded on baseline angiograms with the use of a 4-degree qualitative classification by Rentrop and Cohen²: 0 - no collateral vessels; 1 - filling of side branches of infarct related artery (IRA) via collateral channels without visualization of the epicardial segment; 2 - partial filling of the epicardial segment of IRA via collateral channels; 3 - complete filling of the epicardial segment of IRA via collateral channels. Two experienced cardiologists assessed the coronary angiograms in a blinded fashion and reached a consensus regarding the TIMI flow grade, the collateral flow grade and myocardial blush grade. Patients were divided into 2 groups based on level of CCC as follows: absence of coronary collateral flow (Rentrop 0) and presence of coronary collateral flow (Rentrop 1, 2, 3) Angiographic myocardial blush was graded in a core 
laboratory according to the method described by van't Hof $^{11}$ : 0 , no contrast density or persistent staining; 1 , minimal contrast density; 2 , moderate contrast density, but less than that obtained during angiography of a non-IRA; or 3, normal contrast density, comparable to that obtained during angiography of a non-IRA.

\section{Echocardiograpy}

Following successful recanalization of LAD, a significant improvement of the LV function can be observed echocardiographically approximately $3-5$ hours after the intervention. Therefore, standard two-dimensional echocardiography with a digital ultrasonic device system (iE33; Philips, Netherlands) was performed for each patient in left lateral decubitus position 5 hours after p-PCI. At least 5 consecutive beats were recorded, and the average of values was used for statistical analyses. All recordings were made using a sweep speed of $100 \mathrm{~mm} / \mathrm{s}$, with an electrocardiogram (lead II). Echocardiographic evaluation of the LV function was completed by the assessment of systolic and diastolic diameters, systolic and diastolic volume. Modified Simpson's method was used to assess the left ventricular ejection fraction (LVEF).

\section{In-hospital clinical course}

Adjunctive medical therapy followed the standards of the coronary care unit. The primary objective of this study was to examine in-hospital death. Secondary objectives were to examine the occurrence of advanced heart block, ventricular arrhythmias (ventricular fibrillation and ventricular tachycardia) requiring treatment, hypotension necessitating intraaortic balloon pump (IABP) or pharmacological hemodynamic support. Mechanical complications included free wall rupture, ventricularseptal rupture and severe mitral regurgitation secondaryto corda tendinea or papillary muscle rupture. Cardiogenic shock was characterized by hypotension (defined as systolic blood pressure below $90 \mathrm{mmHg}$ lasting more than 15 minutes or above $90 \mathrm{mmHg}$ under positive inotrop/vasopressor treatment and IABP support), and elevated LV filling pressures in association with signs of tissue hypo-perfusion (cold extremities, cyanosis, oliguria or altered mental status) which were not caused by extra-cardiac causes.

All statistical analyses were performed using the IBM SPSS software (IBM SPSS Statistics for Windows, Version 24.0. Armonk, NY: IBM Corp.) Continuous variables were presented as mean $\pm S D$ whereas categorical variables as count and percentages. The Kolmogorov-Smirnov test was used to evaluate the distribution of continuous variables. Continuous variables were compared with Student's t test or MannWhitney $U$ test according to the distribution of the data. Categorical variables were compared with chisquare or Fisher's exact tests when ever appropriate. Univariate and multivariate logistic regression analyses were conducted to assess association of CCC and inhospital mortality. In stepwise multivariate regression analysis (Backward, Wald), effect size was adjusted for all variables with a univariate significance level of $<0.2$. Adjusted odds ratios (OR), along with their 95\% CIs were presented. A 2-tailed $p$ value of $<0.05$ was considered statistically significant.

\section{Results}

A total of 220 patients $34 \%$ of patients had CCC, mean age was of $61.4 \pm 12.3$ years with first acute Anterior STEMI undergoing p-PCI were included the study. The present study consisted of 64 female (29\%) and 156 male $(71 \%)$ patients. There were no statistically significant differences in respect to demographic characteristics, risk factors of coronary artery disease, LVEF, KILLIP classes, time from symptomps onset to PCI and door to baloon time between the groups. Also there were no statistically significant differences in respect to antiaggregant therapies, other medications given in the hospital and IABP support between the groups (Table 1). There were not found statistically differences in respect to number of diseased coronary arteries, preprocedural TIMI flow and MBG grade and postprocedural TIMI flow (succesful/unsuccesful PCI) between the groups (Table 2). Clinical outcomes were shown in Table 3. There were not found statistically significant differences when compared to the groups with clinical outcomes which included cardiogenic shock on admission, cardiogenic shock in-hospital, fatal ventricular arrhtymias, complet AV block, mechanical complications and in-hospital mortality. In a stepwise backward multivariable model, when all univariate $(\mathrm{p}<0.05)$ predictors of in-hospital mortality were considered, the independent prognostic indicators were age (odds ratio [OR] 1.08, 95\% CI 1.07 to $1.26, \mathrm{p}=0.03$, Time from symptoms onset to PCI; odds ratio [OR] $1.6,95 \% \mathrm{CI} 1.06$ to $2.59, \mathrm{p}=0.04)$ and unsuccessful p-PCI (OR 3.3, 95\% CI 1.04 to 10.9, $\mathrm{p}=0.04)$. 
Table 1. Baseline clinical, echocardiographic characteristic sand in-hospital theraphy

\begin{tabular}{|c|c|c|c|}
\hline \multirow[t]{2}{*}{ Variables } & \multicolumn{2}{|c|}{ Coronary collateral circulation } & \multirow[t]{2}{*}{$\mathrm{p}$ value } \\
\hline & Absent $(n=144)$ & Present $(n=76)$ & \\
\hline Age (years) & $60.5 \pm 11.9$ & $63.3 \pm 13.2$ & 0.11 \\
\hline Male [n (\%)] & $116(80.6)$ & $57(75.0)$ & 0.34 \\
\hline Hypertension [n (\%)] & $44(30.6)$ & $20(26.3)$ & 0.51 \\
\hline Hyperlipidemia [n (\%)] & $32(22.2)$ & $14(18.4)$ & 0.50 \\
\hline DiabetesMellitus [n (\%)] & $31(21.5)$ & $16(21.1)$ & 0.93 \\
\hline Smoke [n (\%)] & $65(45.1)$ & $35(46.1)$ & 0.89 \\
\hline Family History of CAD [n (\%)] & $59(41.0)$ & $29(38.2)$ & 0.68 \\
\hline Previous PCI[n (\%)] & $18(12.5)$ & $10(13.2)$ & 0.89 \\
\hline Time from symptoms onset to $\mathrm{PCl}$ (hours) & $3.1 \pm 1.11$ & $3.17 \pm 0.95$ & 0.15 \\
\hline Door to balloon time (minutes) & $42 \pm 6.2$ & $41.7 \pm 6.3$ & 0.24 \\
\hline LV EF (\%) & $41.0 \pm 10.5$ & $45.2 \pm 10.0$ & 0.06 \\
\hline KILLIP Class & & & 0.80 \\
\hline KILLIP I & $87(60.4)$ & $46(60.5)$ & \\
\hline KILLIP II & $39(27.1)$ & $22(28.9)$ & \\
\hline KILLIP III & $7(4.9)$ & $3(3.9)$ & \\
\hline KILLIP IV & $11(7.6)$ & $5(6.6)$ & \\
\hline \multicolumn{4}{|l|}{ In-hospital therapy } \\
\hline Aspirin [n (\%)] & $137(95.1)$ & $71(93.4)$ & 0.59 \\
\hline ACEI-ARA [n (\%)] & $91(63.2)$ & $49(64.5)$ & 0.85 \\
\hline Clopidogrel [n (\%)] & $123(85.5)$ & $64(84.3)$ & 0.80 \\
\hline Ticagrelor [n (\%)] & $21(14.5)$ & $12(15.7)$ & 0.68 \\
\hline Statin [n (\%)] & $128(88.9)$ & $68(89.5)$ & 0.89 \\
\hline Glycoprotein llb/llla inhibitor [n (\%)] & $40(27.8)$ & $24(31.6)$ & 0.58 \\
\hline IABP [n (\%)] & $20(13.8)$ & $9(11.8)$ & 0.80 \\
\hline
\end{tabular}

Data are expressed as mean $\pm \mathrm{SD}$ for normaly distributed data or count (percentage) for categorical va-riables; ACEI-ARA, angiotensin-converting enzyme inhibitor-angiotensin II receptor antagonist; CAD, Coronary artery disease; IABP; intra-aortic balon pump; LV EF, Left ventricular ejection fraction; MI, Myocardial infarction; PCl, Percutaneous coronary intervention

Table 2. Preprocedural and postprocedural angiographic characteristics related to coronary collateral circulation

\begin{tabular}{|c|c|c|c|}
\hline \multirow[t]{2}{*}{ Variable } & \multicolumn{2}{|c|}{ Coronary collateral circulation } & \multirow[t]{2}{*}{$\mathrm{p}$ value } \\
\hline & Absent $(n=144)$ & Present $(n=76)$ & \\
\hline \multicolumn{4}{|l|}{ Preprocedural } \\
\hline Number of diseased coronary arteries & & & 0.25 \\
\hline $1[\mathrm{n}(\%)]$ & $90(62.5)$ & $41(53.9)$ & \\
\hline $2[\mathrm{n}(\%)]$ & $39(27.1)$ & $25(32.9)$ & \\
\hline $3[n(\%)]$ & $15(10.4)$ & $10(13.2)$ & \\
\hline TIMI flow before PCl & & & 0.98 \\
\hline TIMI 0 [n (\%)] & $123(85.4)$ & $65(85.5)$ & \\
\hline TIMI 1 [n (\%)] & $21(14.6)$ & $11(14.5)$ & \\
\hline $\mathrm{MBG}$ grade before $\mathrm{PCl}$ & & & 0.59 \\
\hline MBG 0-1 & $132(91.7)$ & $68(89.5)$ & \\
\hline MBG 2 & $12(8.3)$ & $8(10.5)$ & \\
\hline \multicolumn{4}{|l|}{ Postprocedural } \\
\hline TIMI flow after $\mathrm{PCl}$ & & & 0.95 \\
\hline Unsuccesful (TIMI 0-1) [n (\%)] & $15(10.4)$ & $8(10.5)$ & \\
\hline Succesful (TIMI 2-3) [n (\%)] & $129(89.6)$ & $68(89.5)$ & \\
\hline
\end{tabular}

Data are expressed as mean \pm SD for normaly distributed data or count (percentage) for categorical variables; MBG, myocardial blush grade; $\mathrm{PCl}$, Percutaneous coronary intervention; TIMI, Thrombolysis In Myocardial Infarction 
Table 3. Clinical Outcome according to presence and absence of CCC

\begin{tabular}{lccc}
\hline Outcome & & CCC & p value \\
\hline & Absent & Present \\
Cardiogenic Shock on Admission [n (\%)] & $\mathrm{n}=144$ & $\mathrm{n}=76$ & $7(9.2)$ \\
Cardiogenic Shock in hospital [n (\%)] & $15(10.4)$ & $6(7.8)$ & 0.77 \\
Complete AV block [n (\%)] & $10(6.9)$ & $7(9.2)$ & 0.55 \\
VT/VF [n (\%)] & $14(9.7)$ & $9(11.2)$ & 0.90 \\
Mechanical Complications [n (\%)] & $19(13.2)$ & $2(2.6)$ & 0.77 \\
Death [n (\%)] & $4(2.7)$ & $10(13.2)$ & 0.96 \\
\hline
\end{tabular}

AV, Atrioventricular; CCC, Coronary Collateral Circulation; RV, Right Ventricular; VT/NF, Ventricular Tachycardia/Ventricular Fibrillation

\section{Discussion}

In the present study, we found that the presence of CCC to the ischemic myocardium in the early hours of infarction was not an independent predictor of inhospital mortality in patients with anterior STEMI undergone PCI. However by multivariate analysis, age, unsuccesfull primary angioplasty and time from symptoms onset to PCI were independent predictor of mortality in our study. Although EF didn't reach statistical significance between the groups, it was detected higher in the group with CCC which may be limiting the infarct size.

In patients with acute STEMI, a relevant protective role of collaterals has been observed as smaller infarct size, preservation of post-MIcardiac function, reduction in post-MI ventricular dilatation and post-infarct aneurysm formation ${ }^{12}$. Increased collateral flow was also associated with less need for IABP post-PCI and better myocardial blush grade ${ }^{13}$. However, the impact of the CCC on short and long term prognosis of MI is unclear.

Although the exact underlying mechanism for the protective role of collaterals are unclear, different mechanisms have been proposed in the literature. Acute myocardial ischaemia it self leads to QT interval prolongation and QT dispersion, which is associated with fatal arrhythmias. In a study, it was shown that CCC reduced further QT prolongation during vessel occlusion and this may contribute to the reduced mortality in patients with a well-developed CCC $^{14}$. The collateral circulation has been also demonstrated to have clinical benefits regarding smaller infarct size, preservation of post-MI cardiac function, and reduction in post-infarct ventricular dilatation ${ }^{15}$. Over the long term, these effects are likely to contribute to a reduced mortality.

Despite the above mentioned machanisms, clinical trials revealed conflicting results. A meta-analysis of 12 studies and 6529 patients showed that the CCC is associated with relatively improved survival. The result was consistent both in patients underwent PCI or a diagnostic angiogram only, or in case of collaterals detected visually or with CFI. Subgroup analyses indicated a clearly prolonged survival of well-collateralized patients with stable CAD while the analyses for subacute and acute MI showed comparable risk reductions but without statistical significance ${ }^{16}$. Another a meta-analysis of nine studies comprising 6791 patients showed that the coronary collateral circulation was associated with relatively improved survival and fewer reinfarctions with statistical significance ${ }^{17}$.

Several factors may cause these conflicting results. Firstly different study population such as patient with stable CAD, acute MI and subacute MI were included in these meta analysis. Also in most of the studies involving acute STEMI, localization of the myocardial infarction was not specified. Whereas, it is known that anterior wall STEMI have highest in-hospital mortality among patients with acute STEMI. There are only a few studies investigated impact of CCC on in hospital mortality in the literature. One of these studies enrolled 190 patients with anterior STEMI treated by primary angioplasty within the first $6 \mathrm{~h}$ of the onset of symptoms investigated assocciation between CCC and in-hospital outcomes ${ }^{18}$. Collateral flow to the infarctrelated artery before angioplasty was angiographically assessed by Rentrop classification, 65 patients (36\%) 
were detected to have collateral vessels. They found that CCC decreased in-hospital mortality by reducing the incidence of cardiogenic shock. Subgroup anlysis of another acute STEMI study reported that presence of CCC with LAD-related infarcts was associated with lower Killip class, smaller infarct size and lower IABP support but without significant in-hospital mortality ${ }^{13}$. Saroja et al..$^{19}$ reported that among patients undergoing primary PCI for acute STEMI within 6 hours of symptom onset, the presence of collateral flow to the infarct zone was dependent on the IRA and, following statistical adjustment for infarct location, was not associated with significant differences in myocardial or microvascular reperfusion rates, infarct size, or subsequent clinical outcomes.

Symptom onset to reperfusion time may play important role both in development of collateral vessels or in-hospital outcomes. During the first 3 to 6 hours of acute coronary synd rome, angiographically well visible collateral vessels develop in nearly half of patients, and the rate increases in the presence of continuing vascular occlusion ${ }^{20}$. Desch et al. ${ }^{21}$ reported a larger proportion of patients showing well-developed collateral flow after 6 th hoursof the symptom onset. But in the study by Steg et al. ${ }^{22}$, angiographic collaterals were only marginally beneficial on all cause mortality which is directly related to the inclusion of about half the patients in subacute MI population with delayed arteriogenesis occurring only after the myocardial salvaging window of the 1 st 3 to 6 hours after symptom onset. Similiar to other studies, $34.5 \%$ of patients with anterior STMI undergone PCI with high success rate within first 6 hours after sypmtoms onset had CCC in our study. Additionally, it is known that various factors such as age, DM, previous angina and genetic features have impact on development of collateral vessels ${ }^{6}$. But these factors were not investigated in our study.

Different methods are used to quantify the coronary collateralcirculation. In the past, only angiographic methods have beenused to measure the extent of the human coronary collateral circulation ${ }^{2}$. Several studies alsoinvestigated collateral flow assessment using a Doppler wire ascompared with angiographically measured collateral flow ${ }^{23,24}$. CFI isclosely correlated with signs of ischaemia on a intracoronary ECG or angina pectoris during coronary occlusion by balloon inflation and is considered the gold standard to assess the capacityof the coronary collateral circulation ${ }^{25,26}$.

\section{Limitation}

This study included only patients who were able to visit hospitals within 24 hours after anterior STEMI onset, and whocould be undergone emergent coronary angiography which revealed complete occlusion of IRA; therefore, there could be a selection bias in this study and it is not clear whether identical conclusions can be drawn for all patients with STEMI. Angiographically detected collateral flow provides only an estimate of existing absolute collateral flow since only collaterals $100 \mu \mathrm{m}$ or more in diameter can be identified. Collateral flow can also be evaluated with methods such as myocardial contrast echocardiography, cardiac nuclear imaging, and pressure-derived collateral flow index with better quantification but indirectly. However their routine uses in clinical practice are not feasible in the setting of acute myocardial infarction treated with PCI.

\section{Conclusions}

The result of this study involving the patients with first acute anterior STEMI revealed that the presence of CCC before PCI may not be associated with in-hospital mortality in contemporary PCI era. Association CCC and mortality should be investigated by largescale studies.

\section{References}

1. Bache RJ, Schwartz JS. Myocardial blood flow during exercise aftergradual coronary occlusion in the dog. Am J Physiol 1983, 245: H131-H138.

2. Rentrop KP, Cohen M, Blanke H, Phillips RA. Changes in collateral channelfilling immediately after controlled coronary artery occlusion by anangioplasty balloon in human subjects. J Am Coll Cardiol 1985, 5:587-92.

3. Wustmann K, Zbinden S, Windecker S, Meier B, Seiler C. Is there functional collateralflow during vascular occlusion in angiographically normal coronary arteries? Circulation 2003;107:2213-20.

4. Werner GS, Ferrari M, Betge S, Gastmann O, Richartz BM, Figulla HR. Collateral function in chronic total coronary occlusions is related toregional myocardial function and duration of occlusion. Circulation 2001, 104:2784-90.

5. Fefer P, Knudtson ML, Cheema AN, Galbraith PD, Osherov $\mathrm{AB}$, Yalonetsky $S$ et al. Current perspectives on coronary chronic total occlusions: The Canadian multicenter chronic total occlusions registry. J AmColl Cardiol 2012;59:991-7. 
6. Van der Hoeven NW, Teunissen PF, Werner GS, Delewi R, Schirmer SH, Traupe T et al. Clinical parameters associated with collateral development in patients with chronic total coronary occlusion. Heart 2013 Aug; 99(15):1100-5.

7. Lee JH, Kim CY, Kim N, Jang SY, Bae MH, Yang DH et al. Coronary collateral function and clinical outcome betwwen patients with acute and chronic total occlusion. JACC Cardiovasc Interv 2017 Mar 27;10(6):585-93.

8. Task Force on the management of ST-segment elevation acute myocardial infarction of the European Society of Cardiology (ESC), Steg PG, James SK, Atar D, Badano LP, BlömstromLundgvist C, Borger MA et al. Eur Heart J 2012 Oct; 33(20):2569-619.

9. Kolh P, Wijns W. Joint esc/eacts guidelines on myocardial revascularization. J Cardiovasc Med (Hagerstown) 2011;12:264-7.

10. Chesebro JH, Knatterud G, Roberts R, Borer J, Cohen LS, Dalen $\mathrm{J}$ et al. Thrombolysis in Myocardial Infarction (TIMI) Trial, Phase I. a comparison between intravenous tissue plasminogen activator and intravenous streptokinase. Clinical findings through hospital discharge. Circulation 1987;76:142-54.

11. Van't Hof AWJ, Lief A, Suryapranata H, Hoorntje JC, de Boer MJ, Zijlstra F. Angiographic assessment of myocardial reperfusion in patients treated with primary angioplasty for acute myocardial infarction. Myocardial blush grade. Circulation 1998;97:2302-6.

12. Seiler C. The human coronary collateral circulation. Eur J Clin Invest 2010;40:465-76.

13. Elsman P, van't Hof AW, de Boer MJ, HoorntjeJC, Suryapranata $\mathrm{H}$, Dambrink JH et al. Role of collateral circulation in the acute phase of STsegment-elevation myocardial infarction treated with primary coronary intervention. Eur Heart J 2004, 25:854-8.

14. Meier P, Gloekler S, de Marchi SF, Zbinden R, Delacretaz E, Seiler C. An indicator of sudden cardiac death during brief coronary occlusion: electrocardiogram QT time and the role of collaterals. Eur Heart J 2010;31:1197-1204.

15. Kim EK, Choi JH, Song YB, Hahn JY, Chang SA, Park SJ et al. A protective role of early collateral blood flow in patients with ST-segment elevation myocardial infarction. Am Heart J 2016 Jan; 171(1):56-63.
16. Meier P, Hemingway H, Lansky AJ, Knapp G, Pitt B, Seiler C. The impact of the coronary collateral circulation on mortality: a meta-analysis. Eur Heart J 2012;33(5):614-21.

17. Akin S, Yetgin T, Brugts JJ, Dirkali A, Zijlstra F, Cleophas TJ. Effect of collaterals on deaths and re-infarctions in patients with coronary artery disease: a meta analysis. Neth Heart J 2013;21:146-51.

18. Pe'rez-Castellano N, Garcia E, Abeytua M, Soriano J, Serrano $\mathrm{JA}$, Elízaqa $\mathrm{J}$ et al. Influence of collateral circulation on inhospital death from anterior acute myocardial infarction. J Am Coll Cardiol 1998;31:512-8.

19. Sorajja P, Gersh BJ, Mehran R, Lansky AJ, Krucoff MW, Webb $\mathrm{J}$ et al. Impact of collateral flow on myocardial reperfusion and infarct size in patients undergoing primary angioplasty for acute myocardial infarction. Am Heart J 2007;154(2):379-84.

20. Waldecker B, Waas W, Haberbosch W, Voss R, Wiecha J, Tillmanns H. Prevalence and significance of coronary collateral circulation in patients with acute myocardial infarct. Z Kardiol 2002;91:243-8.

21. Desch S, de Waha S, Eitel I, Koch A, Gutberlet M, Schuler G et al. Effect of coronary collaterals on long-term prognosis in patients undergoing primary angioplasty for acute ST-elevation myocardial infarction. Am J Cardiol 2010;106(5):605-11.

22. Steg PG, Kerner A, Mancini GB, Reynolds HR, Carvalho AC, Fridrich V et al; OAT Investigators. Impact of collateral flow to the occluded infarct-related artery on clinical outcomes in patients with recent myocardial infarction: a report from the randomized occluded artery trial. Circulation 2010;121:2724-30.

23. Tron C, Donohue TJ, Bach RG, Watford T, Caracciolo EA, Aquirre VF et al. Differential characterization of human coronary collateral blood flow velocity. Am Heart J 1996;132:508-15.

24. Yamada T, Okamoto M, Sueda T, Hashimoto M, Kajiyama G. Relation between collateral flow assessed by Doppler guide wire and angiographic collateral grades. Am Heart J 1995;130:32-7.

25. Seiler C, Fleisch M, Garachemani A, Meier B. Coronary collateral quantitation inpatients with coronary artery disease using intravascular flow velocity or pressuremeasurements. J Am Coll Cardiol 1998;32:1272-9.

26. de Marchi SF, Gloekler S, Meier P, Traupe T, Steck H, Cook $S$ et al. Determinants of preformed collateral vesselsin the human heart without coronary artery disease. Cardiol 2011;118:198-206. 